\title{
Supratentorial Embryonal Tumor, Not Otherwise Specified
}

National Cancer Institute

\section{Source}

National Cancer Institute. Supratentorial Embryonal Tumor, Not Otherwise Specified. NCI

Thesaurus. Code C6968.

A central nervous system embryonal tumor, not otherwise specified arising from the supratentorial region. 